\title{
MENGELOLA SIM DENGAN MEDIA WEBSITE MELALUI PEMBIMBINGAN TEKNIK "MENTARI" DALAM PENINGKATAN KOMPETENSI KEPALA SEKOLAH DI KECAMATAN TAMAN KOTA MADIUN
}

\author{
Yessy Fusvita Dewi \\ yessyfusvita@gmail.com \\ Administrasi Pendidikan \\ Fakultas Ilmu Pendidikan \\ Universitas Negeri Padang
}

\begin{abstract}
ABSTRAK
Persoalan dasar yang muncul disekolah diantaranya yaitu kemampuan manajerial kepala sekolah dalam mengelolah system informasi manajemen sekolah masih dibilang rendah, administrasi sekolah cenderung manual belum mengelola SIM dengan efektif dan efesien. Pembimbingan dengan teknik "MENTARI" adalah salah satu solusinya akronim,dari mengamati,evaluasi dan implementasi dengan media website. Melalui penerapan pembimbingan teknik ini dengan media website dapat meningktakan kompetensi kepala sekolah dalam mengelolah system informasi manajemen, sehingga sekolah diharapkan bisa untuk peningkatan skor hasil dan kenaikan ratarata dengan adanya peningkatan kategori kompetensi.
\end{abstract}

Kata kunci : SIM, Website, Pembimbingan teknik "MENTARI" 


\section{LATAR BELAKANG}

Sebagai seorang administrator, kepala sekolah bertugas untuk membangun manajemen sekolah serta bertanggung jawab dalam pelaksanaan kebijakan sekolah dan dalam keputusan manajemen. Kompetensi manajerial dalam mengelola system informasi manajemen untuk mendukung administrasi pendidikan yang efektif dan efesien merupakan kebutuhan yang tidak dapat dielakkan. Sistem Informasi Manajemen (SIM) merupakan salah satu pemenuhan perubahan yang terjadi di era globalisasi, dijadikan garapan kepala sekolah yang terkait bidang manajerial pada sekolah yang dibinanya dalam peningkatan dan pengembangan kualitas SDM karena dengan adanya kompetisi terhadap dampak global.

Dalam jurnal (Lismawati, 2018) permasalahan rendahnya kompetensi dalam mengelolah system informasi manajemen oleh kepala sekolah, dimana tugas ini dilakukan oleh pihak operator sekolah. Sehingga kepala sekolah membutuhkan pembimbingan untuk mengelola SIM hendaknya bersifat aplikatif, terkait dengan 7 teknik "MENTARI" (Mengamati,Evaluasi,New, Training,Action,Refleksi,Implementasi). 


\section{KAJIAN TEORI/LITERATUR}

Permendiknas No. 39 Tahun 2009 pasal 4 ayat (1) adalah melakukan tugas pembimbingan dan pelatihan professional kepala sekolah dan pengawasan. Langkah-langkah MENTARI tersebut dapat diuraikan sebagai berikut :

a. Mengamati, suatu teknik untuk mendiskripsikan situasi dan tingkat manjerial kepala sekolah dalam pengelolaan SIM di sekolah melalui supervise.

b. Evaluasi, berdasarkan hasil pengamatan untuk menilai tingkat kompeten manajerial kepala sekolah.

c. New, untuk menghasilkan suatu karya baru dengan pemberian motivasi.

d. Training, memberikan pelatihan dengan cara melakukan mengelolah Sistem informasi manjemen sekolah melalui website.

e. Action, kepala sekolah mempraktikkan teori yang ada dalam pelatihan dalam pengelolaan SIM.

f. Refleksi, kepala sekolah menampilkan hasil praktik berupa presentasi

g. Implementasi, terakhir yaitu kepala sekolah menerapkan hasil karya yang sudah dipresentasikan namun yang sudah teruji kelayakannya disekolah.

Sistem Informasi Manajemen, merupakan suatu system dengan menyediakan suatu alat bagi manajer dalam menyusun dan mengelolah departemen secara efesien yang berbasis computer. Tujuan SIM ini diterapkan disekolah sebagai berikut :

- Pihak sekolah : Dalam pengelolaan data supaya mudah, baik itu akademin maupun non akademik, dalam proses pengajaran dapat menyediakn suatu perkembangan siswa berupa laporan, perkembangan pengajar, panduan peraturan sekiolah, memudahkan komunikasi antara masyarakat dan ortu siswa tanpa adanya batas tempat dan waktu, media promosi sekolah, dan sebagai informasi yang luas.

- Pihak orang tua : orang tua mudah untuk memantau perkembangan anak di sekolah, informasi mengenai mata pelajaran, bahan pelajaran dan soal latihan, untuk merencakan dan mengembangkan kemampuan social. 


\section{KAJIAN ANALITIS/PEMBAHASAN}

Ada beberapa yang menjadi factor jika SIM sekolah sukses yaitu adanya ketersediaan, tanpa dipaksa oleh siapa dan apapun, mudah untuk dipahami, adanya kesesuaian dengan semua yang terkait, adanya kelengkapan, adanya ketepatan waktu serta bisa terorganisir sehingga hasil yang diharapkan dapat berjalan efektif, efesien dan produktifitas.

Ruang lingkup SIM meliputi : system informasi yang berupa, profil sekolah, administrasi personalia, kesiswaan, sarpras sekolah, kegiatan akademik, pengelolaan administrasi keuangan, serta layanan infomasi sekolah dan masyarakat.

Material yang dijadikan patokan untuk membuat SIM sekolah diantaranya sebagai berikut : profil siswa/data keseluruhan siswa, subyek/kelas mengenai kelas, peran system sekolah berupa tanggung jawab setiap kelas, kebutuhan peran system sekolah merupakan perencanaan sekolah serta kebutuhan perenacaan sekolah laporan kehadiran siswa,staf sekolah.

Menurut Finch dan Crunkilton (2008 : 145) Kompetensi, merupakan penguasaan terhadap suatu tugas, keterampilan, sikap, dan apresiasi yang diperlukan untuk menunjang keberhasilan. Permendiknas No. 13 Tahun 2007, Kompetensi kepala sekolah bahwa kepala sekolah harus menguasai kompetensi manajerial, kewirausahaan, supervise, kepribadian, dan social.

Dalam jurnal (J. Muhammad dan A.Sabandi, 2019) Implementasi E-rapor menggunakan system informasi manajemen.

Dalam jurnal (Sabandi, 2013) tekhnologi dapat memperluas peningkatan kapasitas guru.

Metodologi penelitian ini dilakukan di sekolah dasar (SDN 03 Taman Kecamatan Taman Kota Madiun Prov Jawa Timur yang terdiri dari 10 sekolah dasar. Dilaksankan pada semester I tahap pembelajaran 2016/2017 selama 4 bulan (September-Desember 2016), pihak yang terkait ketua gugus I dan kepala sekolah di wilayah tersebut. Alat yang digunakan dalam penelitian yaitu teknik non tes dengan penilaian untuk kerja, jurnal, angket, wawancara. Teknik pengolahan data menggunakan analisis deskriptif dan presentase. Prosedur penelitian ini direncanakan dilaksanakan dalam 3 siklus dan masing-masing siklus terdiri atas 2 kali pertemuan. Setiap siklus terdiri atas 4 tahap yaitu perencanaan, tindakan, observasi dan refleksi. 


\section{KESIMPULAN}

Berdasarkan analisis data, dapat tarik simpulannya sebagai berikut :

1. Dapat terjadi peningkatan kompetensi kepala sekolah dalam mengelola SIM dengan media website melalui teknik MENTARI di SD binaan Kecamatan Taman Kota Madiun semester I Tahun pelajaran 2016/2017 dalam setiap siklusnya.

2. Adanya respon yang positif kepala sekolah terhadap pembimbingan teknik MENTARI dalam mengelola SIM tersebut. Kepala sekolah lebih professional dan meningkatnya kemampuan serta kepala sekolah lebih memahami tentang proses administrasi sekolah yang berbasis TIK dan menggunakan waktu secara efektif dan efsien dan mantap.

Ada beberapa saran kepada :

\section{SARAN}

1. Pengawas sekolah, disarankan memotivasi kepala sekolah untuk memanfaatkan computer yang disediakan di sekolah untuk kepentingan dalam pengelolaan SIM dengan media website.

2. Kepala sekolah, dalam pelaksanaan tugas-tugasnya serta untuk meningkatkan kompetensi kepala sekolah diperlukan kerja sama yang antar kepala sekolah.

3. Guru, suatu motivasi dalam meningkatkan kemampuan dalam bidang SIM, inovasi yang selalu berkarya dalam memanfaatkan SIM. 


\section{DAFTAR PUSTAKA}

J. Muhammad dan A.Sabandi. (2019). Persepsi Guru Terhadap Efektivitas Penggunaan E-Rapor Di Sma Negeri 1 Ampek Angkek, Kabupaten Agam. Jurnal Bahana Manajemen Pendidikan, 8(1), 9-17.

Retrieved from http://ejournal.unp.ac.id/index.php/bahana/article/view/103703/pdf

Lismawati. (2018). Peningkatan Kompetensi Kepala Sekolah Dalam Mengelola Sim Dengan Media Website Melalui Pembimbingan Teknik 'Mentari' Di Kecamatan Taman Kota Madiun. Jurnal Edukasi Gemilang, 3(3), 66-79.

Retrieved from https://ejurnalkotamadiun.org/index.php/JEG/article/view/179

Sabandi, A. (2013). Supervisi Pendidikan Untuk Pengembangan Profesionalitas Guru Berkelanjutan. Pedagogi, Jurnal Ilmiah Ilmu Pendidikan, VIII(2), 1-9. Retrieved from http://ejournal.unp.ac.id/index.php/pedagogi/article/view/4275 